\title{
EDUCATING HIGH SCHOOL STUDENTS AND TEACHERS IN RAPID PROTOTYPING AND MANUFACTURING TECHNOLOGIES
}

\author{
Todd Sparks, Vinay Kadekar, Yogesh Thakar, Frank Liou \\ University of Missouri-Rolla
}

\author{
Ashok K Agarwal \\ St. Louis Community College at Florissant Valley
}

\begin{abstract}
$\underline{\text { Abstract }}$
Presented in the paper is an analysis of the experience of teaching rapid prototyping technology to groups of high school students and teachers at a workshop sponsored by NSF during the summer of 2003. This workshop was a collaboratory effort between the University of Missouri-Rolla and the St. Louis Community College at Florissant Valley. Its purpose was to expose high school students and teachers to manufacturing technology in the hope of impacting their career choices. The material presented within the workshop was modified during the course of the summer. The paper reports results of the changes through workshop attendee feedback.
\end{abstract}

\section{Introduction}

It is a common misconception that jobs in the manufacturing industry consist of only machine operators. However, industry's needs are much broader. Manufacturing is more than machining. The personnel needed by the industry must be able to perform multiple functions from design to distribution. In other words, the manufacturing industry needs to be seen holistically - as a complete system involving many people of different educational backgrounds. Companies are looking for individuals with diverse technical expertise to perform multiple functions in support of their manufacturing enterprises.

Many youth and adults have little knowledge of engineering and manufacturing career options. Parents, teachers, and educators lack exposure to the understanding of highly technical manufacturing world. Early education is a key element in engineering and manufacturing career awareness.

Rapid Prototyping is an emerging technology in manufacturing. It is a technique which is a fast and effective way to develop the prototype parts from their CAD models directly. These parts serve the purpose of design evaluation in the early stages of the product life cycle.

The intent of this contribution is to describe the experiences from the NSF-sponsored Discover Manufacturing Workshop conducted at St. Louis Community College at Florissant Valley. The emphasis of the workshop was on exposing the 42 attending high school students and 21 attending teachers to manufacturing technologies with the goal of creating awareness to emerging career opportunities in manufacturing.

Interactive course content with hands on experience was the key towards the success of this program. This paper also discusses the audience background and interests before the workshop. The information about the feedback and observations has been found enlightening and mentioned in the paper.

"Proceedings of the 2004 American Society for Engineering Education Annual Conference \& Exposition Copyright C 2004, American Society for Engineering Education” 


\section{Course Content}

There were four sessions of the 2004 Discover Manufacturing Workshop held at St. Louis Community College at Florissant Valley. The attendees of the first and third sessions were high school teachers. The second and fourth sessions were composed of high school students. Based upon attendee feedback, the program content was altered after the second week.

The content presented on rapid prototyping in the first two weeks of the workshop was taken directly from a 300-level technical elective at UMR. This presentation began with introductory material on prototyping, which led to discussion on rapid prototyping. It included details on the structure of STL files and the mathematic principles behind the slicing operation, as well as detailed information on the FDM and $3 \mathrm{D}$ printing processes and a short video from Stratasys.

After conducting the first two weeks of the seminar, attendee feedback was compiled. The teachers were from varied backgrounds and not all of them could follow the mathematics behind STL files and the slicing operation. They were largely interested in this relatively new area of technology and how it would impact their students in the future. Similarly, the students were confused by the mathematics. Also, the students needed interactivity to keep them focused on the material. Feedback from the students in week 2 is summarized in Figure 1.

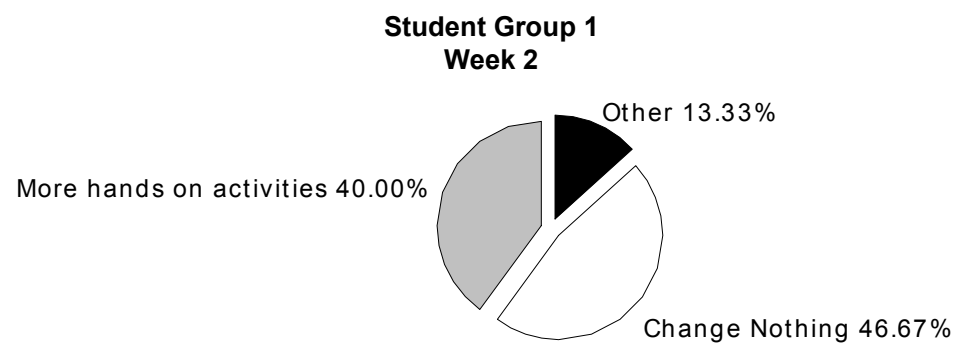

Figure 1 - Student Feedback from Week 2

Based upon the feedback results, it was decided that the course material should be revised. The complex math was replaced with a history of the development of RP technologies and an overview of modern rapid prototyping technologies. The lecture portion of the workshop was streamlined and shortened to make room for more activities. In the third week, the teachers were given the opportunity to create an object in Unigraphics (at the end of the day). That proved to be too daunting, as they were just introduced to Unigraphics on the previous day. On the final week, the students were introduced to Solidworks and given a more structured activity. Feedback from the students in week 4 is summarized in Figure 2. 


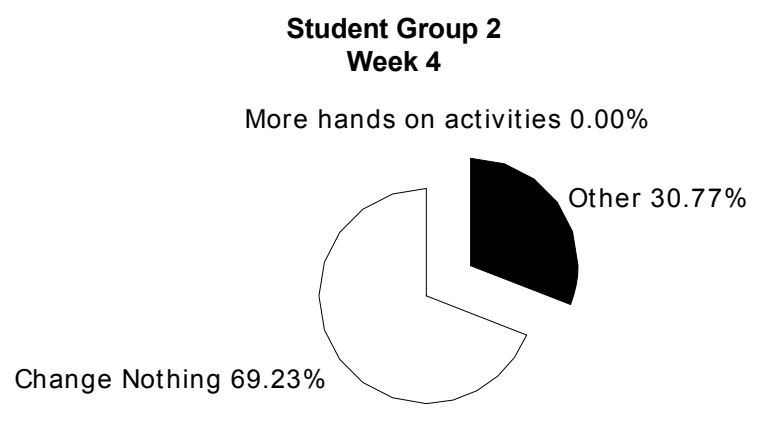

Figure 2 - Student Feedback from Week 4

\section{Schedule}

The workshop was a week long program covering most of the areas in the manufacturing sector. The schedule for the workshop is shown in Table 1.

Table 1-Workshop Schedule

\begin{tabular}{|l|l|}
\hline Mon. & Activities \\
\hline $9 \mathrm{am}$ & $\begin{array}{l}\text { Introductions } \\
\text { and orientation }\end{array}$ \\
\hline $10 \mathrm{am}$ & $\begin{array}{l}\text { Manufacturing } \\
\text { overview }\end{array}$ \\
\hline $10: 40$ & Solid Modeling \\
\hline 11.30 & Lunch Break \\
\hline $12: 15$ & Solid Modeling \\
\hline $2: 15$ & Solid Modeling \\
\hline $3: 45$ & Wrap up day \\
\hline $4 \mathrm{pm}$ & Dismiss \\
\hline
\end{tabular}

\begin{tabular}{|l|l|}
\hline Tue. & \multicolumn{2}{|l|}{ Activities } \\
\hline 9 am & Introductions \\
\hline $9: 15$ & $\begin{array}{l}\text { Rapid } \\
\text { Prototyping } \\
\text { Introduction }\end{array}$ \\
\hline $10: 15$ & $\begin{array}{l}\text { Rapid } \\
\text { Prototyping } \\
\text { Lab }\end{array}$ \\
\hline 11.30 & \multicolumn{1}{|c|}{ Lunch Break } \\
\hline $12: 15$ & $\begin{array}{l}\text { Rapid } \\
\text { Prototyping } \\
\text { Applications }\end{array}$ \\
\hline $2: 15$ & $\begin{array}{l}\text { Rapid } \\
\text { Prototyping } \\
\text { Post processing }\end{array}$ \\
\hline $3: 45$ & Wrap up day \\
\hline $4 \mathrm{pm}$ & Dismiss \\
\hline
\end{tabular}

\begin{tabular}{|l|l|}
\hline Wed. & Activities \\
\hline $9 \mathrm{am}$ & Introductions \\
\hline $9: 15$ & $\begin{array}{l}\text { CNC Machine } \\
\text { Trainers }\end{array}$ \\
\hline 11.30 & Lunch Break \\
\hline $12: 15$ & $\begin{array}{l}\text { Manufacturing } \\
\text { Industry Tour }\end{array}$ \\
\hline $3: 45$ & Wrap up day \\
\hline $4 \mathrm{pm}$ & Dismiss \\
\hline
\end{tabular}

\begin{tabular}{|l|l|}
\hline Thur. & Activities \\
\hline 9 am & Introductions \\
\hline $9: 15$ & $\begin{array}{l}\text { Lean } \\
\text { Manufacturing }\end{array}$ \\
\hline $10: 30$ & $\begin{array}{l}\text { Lean } \\
\text { Manufacturing }\end{array}$ \\
\hline 11.30 & \multicolumn{1}{|c|}{ Lunch Break } \\
\hline $12: 15$ & $\begin{array}{l}\text { Lean } \\
\text { Manufacturing }\end{array}$ \\
\hline $2: 15$ & $\begin{array}{l}\text { Lean } \\
\text { Manufacturing }\end{array}$ \\
\hline $3: 45$ & Wrap up day \\
\hline $4 \mathrm{pm}$ & Dismiss \\
\hline
\end{tabular}

\begin{tabular}{|l|l|}
\hline Fri. & Activities \\
\hline 9 am & Introductions \\
\hline $9: 15$ & Quality Control \\
\hline $10: 30$ & Quality Control \\
\hline 11.30 & Lunch Break \\
\hline $12: 15$ & $\begin{array}{l}\text { Plastic } \\
\text { Processes }\end{array}$ \\
\hline $2: 30$ & Guest Speaker \\
\hline $3: 45$ & Wrap up day \\
\hline $4 \mathrm{pm}$ & Dismiss \\
\hline
\end{tabular}

The week started with an introduction to solid modeling. UniGraphics was one of the tools used to give them hands on experience on the solid modeling. The next day we introduced rapid prototyping which was a new concept to most of them. They had hands on experience on the two machines namely FDM and the Thermaljet. Later in the week they were exposed to $\mathrm{CNC}$, lean manufacturing and quality control.

\section{Software Tools}

During the workshop conducted, various CAD and related software packages were used for the hands on experience to students and teachers. The software packages used are briefly described below:

Unigraphics V18.0: Unigraphics was used for generating the CAD models of the objects to be manufactured during this workshop. These CAD models are converted into .stl format so that it can be read by the rapid prototyping machines to produce the part. The typical Unigraphics user interface is shown in Figure 3. 


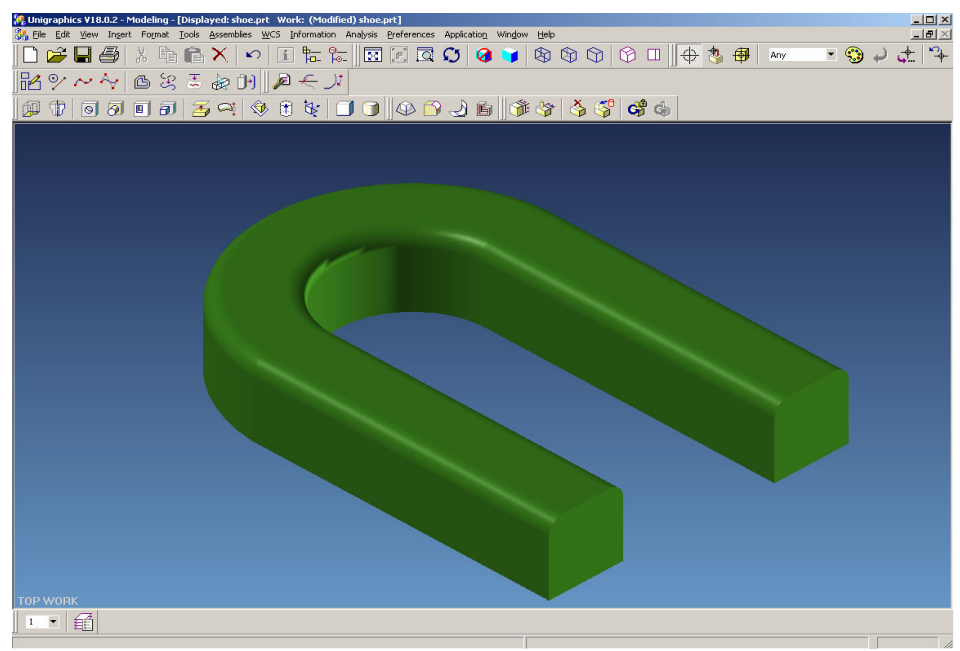

Figure 3 - UniGraphics User Interface

Solidworks: Solidworks was taught to the last group attending the workshop as an alternative to Unigraphics. It is a solid modeling package, much akin to Unigraphics. Solidworks is not as feature-rich as Unigraphics, but it has a shallower learning curve. The typical Solidworks user interface is shown in Figure 4.

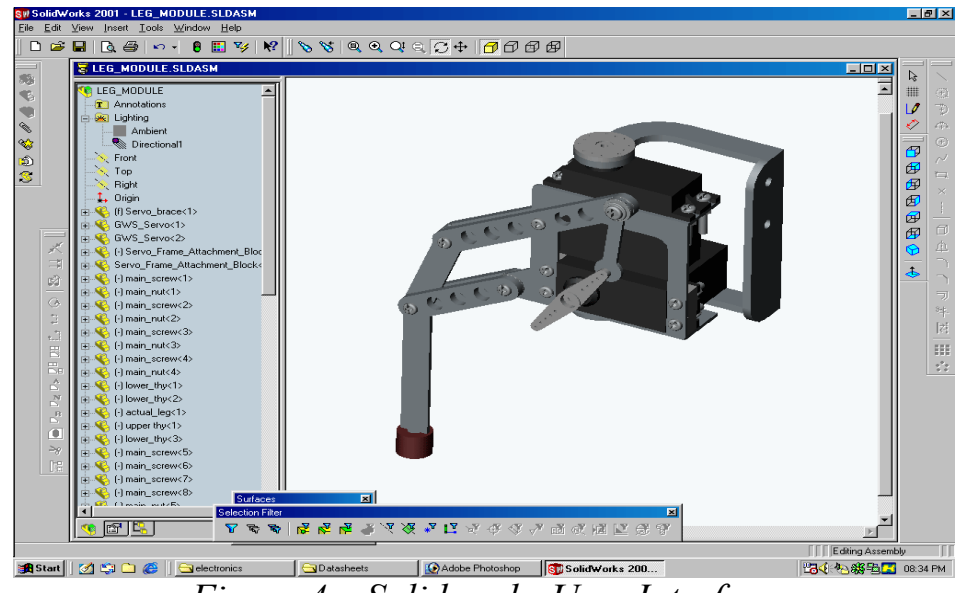

Figure 4-Solidworks User Interface

Insight 5.0: The CAD files which are converted to .stl format are further processed with the software tool called Insight 5.0, provided by Stratasys for use with their FDM machines. Insight generates the layers, tool paths, support structure necessary to build the model, then uploads the information to the FDM machine. It offers the user the ability to precisely control many aspects of the process and reports build time and material usage.

\section{Hardware}

Rapid prototyping machines build models layer by layer using a variety of processes. The process begins with a 3D model from the desired part. The user then loads the 3D model into some proprietary software specific to their rapid prototyping machine. This software cuts the model into a set of stacked 2D layers in a process known as "slicing" and plans the tool paths necessary for the machine to create each layer. This software will also compute the support structure necessary to support the model as it 
is being constructed. Then, the software sends the information necessary to construct the model to the rapid prototyping machine.

St. Louis Community College at Florissant Valley has two such rapid prototyping machines: the Stratasys FDM2000 and 3D System's 3D Thermaljet, as seen in Figures 5 and 6, respectively. The FDM2000 creates parts by extruding plastic through a heated nozzle. The 3D printer creates parts by spraying a wax-like polymer from an ink jet head.

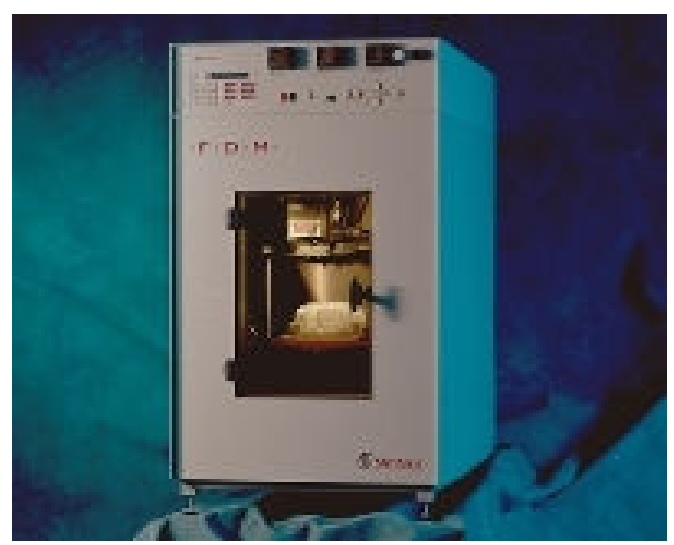

Figure 5 - Stratasys FDM 2000

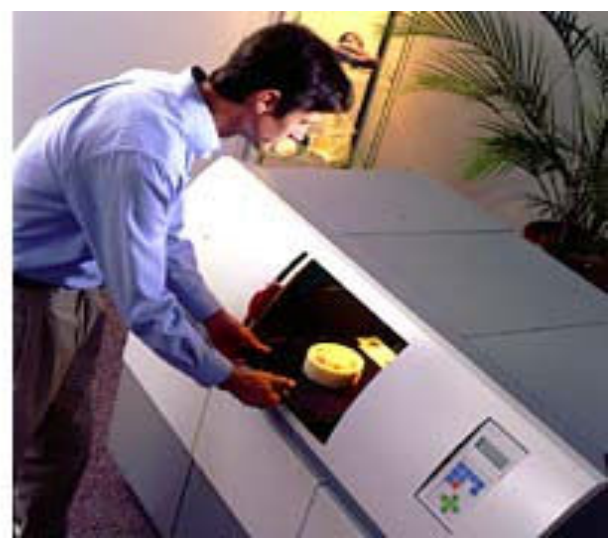

Figure 6-3D Systems Thermaljet

\section{Attendee Background}

Teachers from all backgrounds took part in the workshop. They intended to learn about manufacturing technology and the current developments in the area of manufacturing. With this knowledge they wanted to relate what they teach in the classroom with the real world. Above all, they could guide students about a possible career in the area of manufacturing. The experience of the teachers ranged from 1- 32 years as shown in the Figure 7.

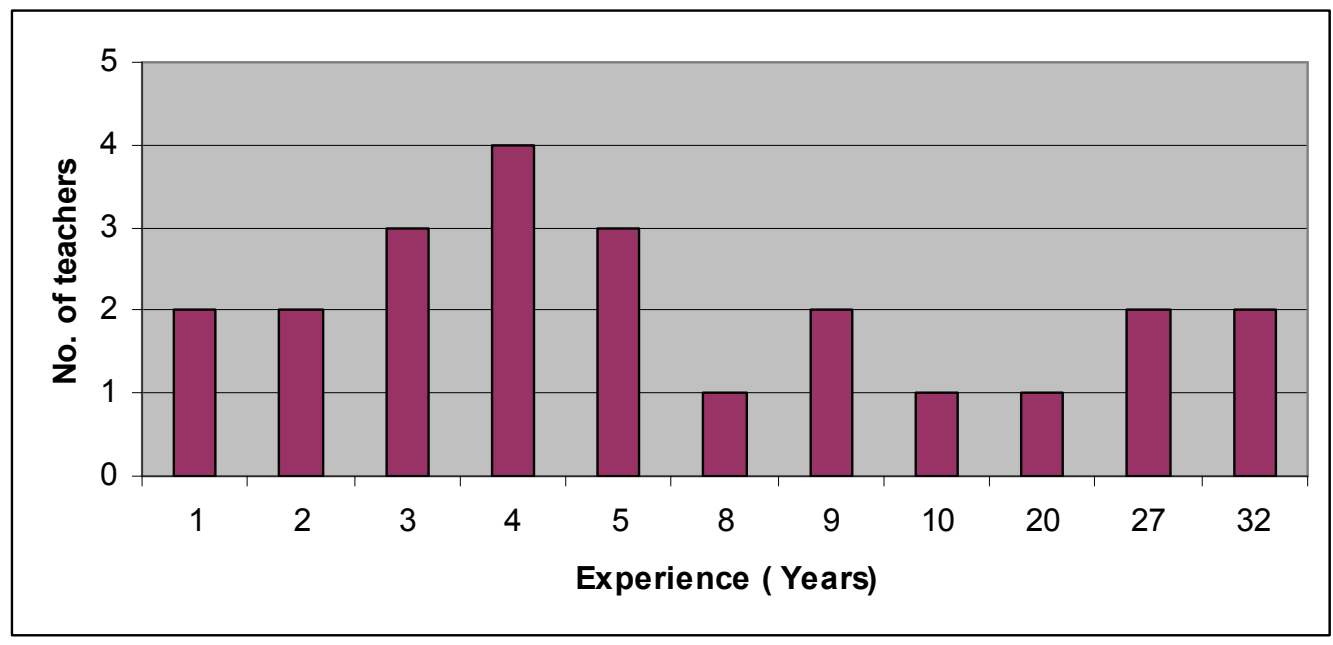

Figure 7 - Attending Teacher Experience

The concept of rapid prototyping was new to the teachers and students attending the workshop. As illustrated in Figure 8, only 14\% of had even heard of rapid 
prototyping prior to the workshop. The only way to overcome this is to educate people and to create awareness on the key elements in engineering and manufacturing career. This workshop at St. Louis Community College was one step towards achieving it.

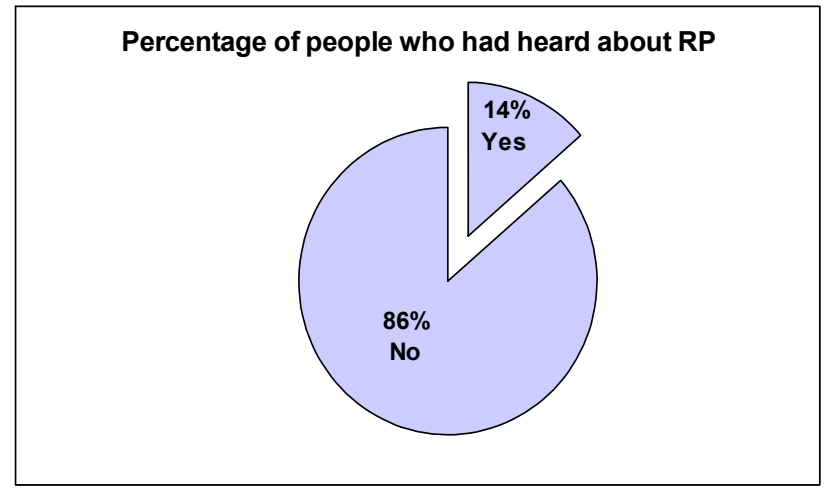

Figure 8-Percentage of people who had heard about RP

\section{Workshop Feedback}

At the end of the day, the workshop attendees were given an opportunity to relate their experience at the workshop through a feedback form. Tables 2 - 4 summarize the feedback obtained from students and teachers. The feedback we got was encouraging: teachers were now able to relate mathematics and computer application with design, drafting and finally to produce the prototypes. They were now in a better position to guide students about the career opportunities in manufacturing.

Table 2 - Feedback Questionnaire Results

\begin{tabular}{|c|c|}
\hline Students & Teachers \\
\hline \multicolumn{2}{|l|}{ Why did you attend the workshop? } \\
\hline $\begin{aligned} & \text { To learn more about my future major. } \\
&> \text { To advance my knowledge in the } \\
& \text { manufacturing process. } \\
&>\text { I was uncertain about my future profession } \\
& \text { so this workshop could give insight about } \\
& \text { this field. } \\
&>\text { To get a better look of how something were } \\
& \text { made by technology. } \\
&>\text { To open up my options of manufacturing } \\
& \text { since it involved my favorite subject. } \\
&>\text { Because my math teacher thought it would } \\
& \text { be good for me. }\end{aligned}$ & $\begin{array}{l}\text { Keep current on developments. } \\
\text { To learn what I need to do in order to } \\
\text { integrate math with real world. } \\
>\text { To learn about manufacturing, to inform } \\
\text { students about this career field. } \\
>\text { To try to make connections between what } \\
\text { I teach and the manufacturing process. } \\
>\text { To find out what careers and technologies } \\
\text { are available for students. } \\
>\text { Better understanding of CNC and } \\
\text { manufacturing to relate to students. }\end{array}$ \\
\hline \multicolumn{2}{|c|}{$\begin{array}{l}\text { After attending this workshop, do you see any connections between this topic with a course you } \\
\text { are taking/teaching? }\end{array}$} \\
\hline $\begin{array}{l}>\text { Yes, most options like the fillet option } \\
\text { where very similar to what we did in } \\
\text { AutoCAD. } \\
>\text { Yes because I am going into aviation. } \\
>\text { Yes with the architectural drafting I have } \\
\text { taken. } \\
>\text { Yes, I do and I plan to major in this subject. } \\
>\text { There is a connection between this course } \\
\text { and algebra II. }\end{array}$ & $\begin{array}{l}\text { Yes, as students develop own products, } \\
\text { can receive better understanding of the } \\
\text { design, production and manufacturing. } \\
\text { I'm beginning to see connections, } \\
\text { generally with the presentations and the } \\
\text { ability to communicate effectively. } \\
\text { Definitely, as a math teacher I see } \\
\text { mathematical and geometric connections } \\
\text { in designing, drafting and finally } \\
\text { producing the prototype. } \\
>\text { Yes, I use a variety of technology in class. }\end{array}$ \\
\hline
\end{tabular}


Table 2, above, addresses the relevance of the workshop. Both teachers and students were able to see connections between the workshop and the profession (or planned profession). Tables 3 and 4, below, ask the attendees which topics were of the most interest to them. Both teachers, Table 3, and students, Table 4, found rapid prototyping and industrial design to be a engaging topics.

Table 3 - Teachers: What Sub-Topic(s) are most interesting to you?

\begin{tabular}{|l|l|}
\hline \multicolumn{1}{|c|}{ Teacher Comment } & \multicolumn{1}{|c|}{ Notes } \\
\hline The FDM fused deposition modeling. & $\begin{array}{l}\text { At the end of the day, workshop attendees were } \\
\text { introduced to research at the Laser Aided } \\
\text { Manufacturing Process laboratory at UMR. }\end{array}$ \\
\hline Hands on activity with the LAMP. & \\
\hline $\begin{array}{l}\text { The FDM process in general to learn the use of } \\
\text { different polymers can result in working parts. }\end{array}$ & \\
\hline $\begin{array}{l}\text { Modeling in the computer using Unigraphics. } \\
\text { whe FDM machine's ability to mold prototypes } \\
\text { with moving parts. }\end{array}$ & \\
\hline $\begin{array}{l}\text { Enjoyed participating in the production process } \\
\text { from modelling to drafting the rapid prototype } \\
\text { processing and seeing the machines work. }\end{array}$ & \\
\hline $\begin{array}{l}\text { Prototyping is the way of the future. } \\
\text { pointed this workshop in the direction of } \\
\text { understanding how this technology works. }\end{array}$ & $\begin{array}{l}\text { A guest speaker from an industrial design firm } \\
\text { introduced the workshop attendees to industrial }\end{array}$ \\
\hline $\begin{array}{l}\text { The material used in the prototyping, 3D } \\
\text { modelling with Unigraphics, industrial design. }\end{array}$ & \\
\hline
\end{tabular}

Table 4 -Students: What Sub-Topic(s) are most interesting to you?

\begin{tabular}{|l|l|}
\hline \multicolumn{1}{|c|}{ Student Comment } & \multicolumn{1}{|c|}{ Notes } \\
\hline Manufacturing. & \\
\hline $\begin{array}{l}\text { How prototypes are made and what can be } \\
\text { made out of a prototype. }\end{array}$ & \\
\hline Titan/CAD/CAM. & $\begin{array}{l}\text { A guest speaker from an industrial design firm } \\
\text { introduced the workshop attendees to industrial } \\
\text { design. }\end{array}$ \\
\hline The industrial engineer speech. & \\
\hline $\begin{array}{l}\text { Industrial design. } \\
\text { manufacturing. }\end{array}$ & \\
\hline $\begin{array}{l}\text { I learned what prototyping is, and the different } \\
\text { fields of engineering. }\end{array}$ & \\
\hline $\begin{array}{l}\text { Prototyping is just a play model of what your } \\
\text { idea is. }\end{array}$ & \\
\hline Using Solid Works. & \\
\hline The different types of laser tech. & \\
\hline $\begin{array}{l}\text { About the cost and time of making the } \\
\text { prototypes. }\end{array}$ & \\
\hline $\begin{array}{l}\text { The processes you go through to get the final } \\
\text { product. }\end{array}$ & \\
\hline
\end{tabular}


When asked about plans for secondary education, students responded with a variety of answers. Nearly $44 \%$ of the students attending the workshop were unsure of what they were going to study post-high school. Only $9 \%$ had decided to pursue a field in manufacturing or engineering. The remainder of the students showed interests in things varying from military service to journalism or medicine. Select student comments are shown below in Table 5 .

Table 5 - Student's Plans for the Future

\begin{tabular}{|ll|}
\hline & What is your plan for post-high school education? \\
\hline$>$ & To go to college to be an architect. \\
\hline$>$ & A career in manufacturing. \\
\hline$>$ & Four year college and a major in computer science. \\
\hline$>$ & A technical college. \\
\hline$>$ & Military or manufacturing career. \\
\hline
\end{tabular}

\section{Conclusions and Suggestions}

The rapid prototyping session 2004 Discover Manufacturing Workshop was successful in introducing new technologies and concepts to the workshop attendees. Also, the workshop faculty learned a great deal about dealing with students from varied backgrounds. In the future, feedback forms could be designed to examine changes in the attendees' responses before and after the workshop. Feedback forms such as the ones illustrated in Tables 6 and 7 would correlate responses before the workshop to responses after the workshop. This information would be helpful in determining if the workshop was helpful in assisting the students with selecting a career.

Table 6 - Proposed Pre-Workshop Background Form

\begin{tabular}{|ll|}
\hline \multicolumn{2}{|c|}{ Workshop Attendee Background Questionnaire (Student) } \\
\hline$>$ & $\begin{array}{l}\text { Why did you choose to attend the workshop? } \\
\text { manufacturing technology? }\end{array}$ \\
\hline$>$ & When will you graduate from High School? \\
\hline$>$ & What are your post-high school plans? \\
\hline$>$ & What do you expect to learn from today's topic? \\
\hline$>$ & $\begin{array}{l}\text { On a 1-5 scale, how would you rate your understanding of } \\
\text { manufacturing technology? (1= little understanding, } \\
5=\text { great understanding) }\end{array}$ \\
\hline & Workshop Attendee Background Questionnaire (Teacher) \\
\hline$>$ & What subject(s) do you teach? \\
\hline$>$ & $\begin{array}{l}\text { Do you have any experience teaching a manufacturing } \\
\text { related topic? If so, how many years of experience do } \\
\text { you have? }\end{array}$ \\
\hline$>$ & Why did you choose to attend the workshop? \\
\hline$>$ & What do you expect to learn from today's topic? \\
\hline & $\begin{array}{l}\text { On a 1-5 scale, how would you rate your understanding } \\
\text { of manufacturing technology? (1) little understanding, } \\
5=\text { great understanding) }\end{array}$ \\
\hline
\end{tabular}


Table 7 - Proposed Post-Workshop Feedback Form

Workshop Attendee Feedback Questionnaire (Student)

\begin{tabular}{|ll|}
\hline$>$ & Have your post-high school plans changed? \\
\hline$>$ & What was your favorite topic of the day? \\
\hline$>$ & $\begin{array}{l}\text { Should any of the material be omitted from future } \\
\text { workshops? If so, what material? }\end{array}$ \\
\hline$>$ & $\begin{array}{l}\text { Would you have liked more detail on any particular topic? } \\
\text { If so, what topic? }\end{array}$ \\
\hline$>$ & $\begin{array}{l}\text { Do you see any correlation between today's topics and the } \\
\text { courses you are taking? }\end{array}$ \\
\hline$>$ & Overall, what is your opinion of today's topic? \\
\hline & $\begin{array}{l}\text { On a 1-5 scale, how would you rate your understanding of } \\
\text { manufacturing technology? (1= little understanding, } \\
5=\text { great understanding) }\end{array}$ \\
\hline$>$ & Workshop Attendee Feedback Questionnaire (Teacher) \\
\hline$>$ & $\begin{array}{l}\text { What was your favorite topic of the day? } \\
\text { workshops? If so, what material? }\end{array}$ \\
\hline$>$ & $\begin{array}{l}\text { Would you have liked more detail on any particular } \\
\text { topic? If so, what topic? }\end{array}$ \\
\hline$>$ & $\begin{array}{l}\text { Do you see any correlation between today's topics and } \\
\text { the courses you are teaching? }\end{array}$ \\
\hline$>$ & \begin{tabular}{l} 
Overall, what is your opinion of today's topic? \\
\hline$>$
\end{tabular} \\
$\begin{array}{l}\text { On a 1-5 scale, how would you rate your understanding } \\
\text { of manufacturing technology? (1= little understanding, } \\
5=\text { great understanding) }\end{array}$ \\
\hline
\end{tabular}

In the future, such workshops should focus on activities. While lectures are necessary for laying groundwork for more interesting activities, most of the feedback received during workshop asked for more time with hands-on activities.

\section{Acknowledgments}

This project is supported by NSF DUE-0202247 and the Society of Manufacturing Engineers Education, Foundation Grant Number 010291. Their support is appreciated.

\section{Bibliography}

1. Grenada, Edward, "Worldwide Guide to Rapid Prototyping," retrieved June 30, 2003 from http://home.att.net/ castleisland/

2. Mikael, "MHEX the Hexapod Robot," retrieved Oct. 16, 2003 from http://www.geocities.com/viasc/mhex/mhex.htm

\section{$\underline{\text { XI. Biographical Sketches }}$}

TODD SPARKS: Todd Sparks is a Doctorate student of Mechanical Engineering program at the University of Missouri- Rolla (UMR). He is currently involved in research of the Laser Aided Manufacturing Processes (LAMP) and rapid prototyping under the guidance of Dr. Frank Liou at UMR. He received GAANN fellowship in summer 2003.

VINAY KADEKAR: Vinay Kadekar is a Master's student of Mechanical Engineering program at the UMR. His field of research is micromachining using LASER under the guidance of Dr. Frank Liou at UMR. 
YOGESH THAKAR: Yogesh Thakar is a Master's student of Manufacturing Engineering program at the UMR. His research concentration is in the field of the Laser Aided Manufacturing Processes (LAMP) and rapid prototyping under the guidance of Dr. Frank Liou at UMR.

FRANK LIOU: Frank Liou is a Professor of Mechanical Engineering Department at the University of Missouri-Rolla (UMR). He currently serves as the Director of the Manufacturing Engineering Education Program (MEEP) at UMR. His teaching and research interests include $\mathrm{CAD} / \mathrm{CAM}$, rapid prototyping, rapid manufacturing, and augmented reality. He has published over 80 technical papers, and has research grants and contracts over $\$ 5 \mathrm{M}$.

ASHOK. K. AGRAWAL, P.E.: Ashok. K. Agrawal is Chairman and Professor, Engineering and Technology Department, St. Louis Community College,. Recently completed one-year term as a Program Director, Advance Technology Education (ATE), Division of Undergraduate Education, National Science Foundation. His primary responsibilities included management of the ATE and engineering projects, and interaction with college and university faculty from across the country. 